BioLink : Jurnal Biologi Lingkungan, Industri dan Kesehatan, Vol. 7 (2) Feb (2021) ISSN: 2356- 458X (print) ISSN: 2597-5269 (online)

\title{
BioLink
}

Jurnal Biologi Lingkungan, Industri, Kesehatan

Available online http://ojs.uma.ac.id/index.php/biolink

\section{VEGETATION COMPOSITION ON ECOLOGICAL FUNCTION IN MATARAM MERAH PARK, JAKARTA}

\author{
Nur Intan Simangunsong*, Rini Fitri, \& Qurrotu Aini Besila
}

Department of Landscape Architecture, Faculty of Landscape Architecture and Environmental Technology, Universitas Trisakti, Indonesia

Submited : 15-06-2020; Reviewed :10-09-2020; Accepted : 23-11-2020

${ }^{*}$ Corresponding author: E-mail : nurintan@trisakti.ac.id

\begin{abstract}
The existence of the city park is important for Jakarta as a metropolitan city with the current activity level of motor vehicles and air pollution greatly affects the quality of the city environment. The selection of vegetation in Mataram Merah park considered functional aspects and aesthetic values. The objective of this study were to determine the composition and type of vegetation landscape in Mataram Merah park and to determine the function of each type of landscape vegetation in Mataram Merah park. This study used a descriptive qualitative method with several stages, which is survey; identification of the name and type of vegetation; size identification; identification of the type of vegetation making up the composition (name of type and size that makes up the vegetation structure). The results showed that Mataram Merah park was generally planted with vegetation that functioned aesthetically rather than functionally. The function of landscape plants in Mataram Merah park were as aesthetics is $96.55 \%$, as controlling view as much as $13.80 \%$, vegetation function as physical barrier as much as $62.07 \%$, plants as controlling erosion $51.72 \%$, function of plants as controlling climate $13.79 \%$ and vegetation function for wildlife as much as $17.24 \%$.
\end{abstract}

Keywords: Vegetation composition; Ecological function; Park

How to Cite: Simangunsong, N.I., Fitri, R., \& Besila, Q.A. (2021). Vegetation Composition on Ecologcal Function In Jakarta Mataram Merah Park, BioLink: Jurnal Biologi Lingkungan, Industri dan Kesehatan, Vol.7 (2): Hal. 123- 129 


\section{INTRODUCTION}

Green open space (RTH) in the form of a city park is one of the public facilities that can be enjoyed by urban communities. This park is provided by the city government so that it can be enjoyed by all city residents (Yuantika \& Sulistiyowati, 2019). Regulation of the Minister of Public Works Number 05 / PRT / M / 2008 states that the government is obliged to provide a minimum of $30 \%$ RTH consisting of $20 \%$ land / urban area for RTH (public / park) plus $10 \%$ RTH which is private or belongs to people who already have control over the land (park or yards planted with plants).

To fulfill the requirements of $30 \%$ $\mathrm{RTH}$, it is necessary to plan and collaborate with various parties, namely collaboration between stakeholders, increasing community participation and strengthening regulations that are carried out consistently and continuously. (Herdiansyah \& Prakoso, 2019)

Green Open Space has an important role in the image of a city, among them are as a landmark, a 'mouthpiece for the people', a place for community interaction, a place that can accommodate people's aspirations, and has its own historical value (Ayu, 2019). Green Open Space (RTH) in the form of city parks can be utilized by urban communities for various social activities in a city or part of an urban area supported by sports facilities, children's playgrounds, special parks for the elderly, flower gardens, recreational facilities and all these facilities are regulated in Regulation of the Minister of Public Works Number 05 / PRT / M / 2008 states that it is open to the public. The criteria for city parks are categorized as good, namely easy to access, neatly arranged, providing a sense of comfort and safety for its users and allowing for many social interactions (Hanan, 2013).

The existence of city parks is very important for DKI Jakarta as a metropolitan city with a high level of activity; of course it greatly affects the carrying capacity of the environment, namely increasing air pollution and motor vehicles. City parks have long been considered as sanctuaries from noise and pollution around the city (Brimblecombe \& Xing, 2019)

City parks does not only function ecologically but also as public spaces for the interaction of urban communities in the midst of their busy activities; Proper use of landscape plants can reduce pollutant levels (Alfian \& Kurniawan, 2010; Rizkiyah et al., 2016). The conceptual green open space planning (city parks) can control global problems and ecosystem degradation in urban areas and meet ecological and environmental needs. Along with its development, city parks are not only limited to places for relaxing and 
picnic activities, as well as active selection of functional landscape recreational activities, sports, cultural svegetation and provide aesthetic value to activities, entertainment and social Mataram Merah Park. The objective of this interactions. City parks also have various study were to determine the composition other functions, namely ecological, of the species, the size of the vegetation in biological, hydrological, aesthetic, Mataram Merah Park landscape and to recreational and social (Nurbalkis \& Nurini, determine the function of each type of 2016). landscape vegetation in Mataram Park.

Mataram Merah Park is a city park that functions as a green open space for residents of Selong Village, Kebayoran Baru Jakarta. Considering the importance of the ecological function of vegetation in city parks for environmental quality, it is this city park can be seen in (Figure 1). necessary to study how to plan the

\section{MATERIALS AND METHODS}

This research was conducted in March 2020, in Mataram Merah Park, Jakarta. The study area and the position of

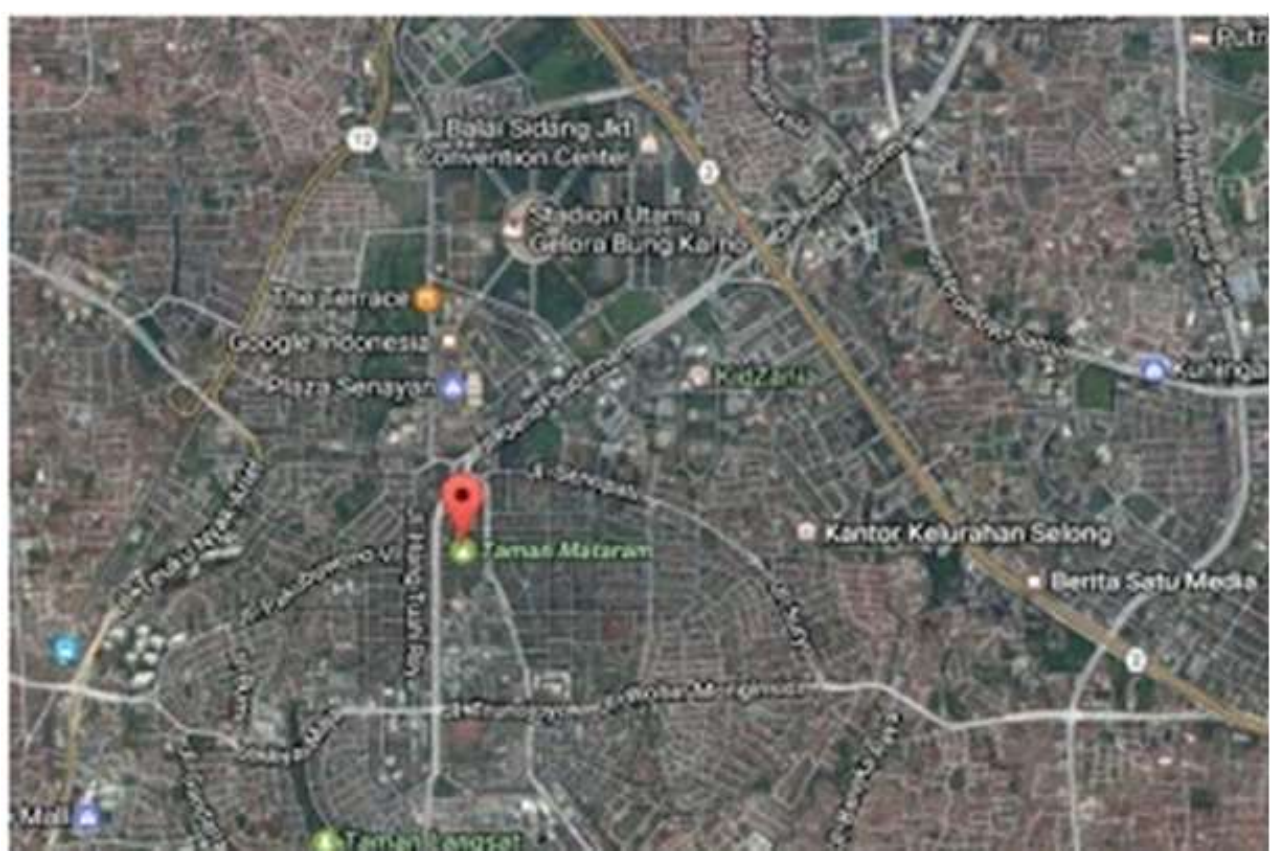

Figure 1. Map of the Research Location

Source: Google Earth (downloaded 29 April 2020 at 9:31 WIB)

This study used a qualitative object of research. This stage identified the descriptive method, this method carried types of vegetation composing plants out data collection activities consisting of throughout Mataram Park (local names, two stages, namely the first stage of scientific names and sizes that make up the collecting data through a survey of the vegetation structure). The second stage 
was to analyze the types of plants (Table 1), its ecological function in the landscape with the tree size specifications are based on reference to several sources and validated (Irwan, 2007) and descriptive analysis of by a team of experts.

Table 1. Tree types and specifications

\begin{tabular}{clccccc}
\hline \multirow{2}{*}{ No. } & \multicolumn{1}{c}{ Tree Size } & Combination of Height & \multicolumn{2}{c}{ Tree Height (m) } & \multicolumn{2}{c}{ Head Width (m) } \\
\cline { 3 - 6 } & & and Header Width & Code & High & Code & Wide \\
\hline 1 & Small Tree (S) & Aa, Ab & A & $<5$ & a & $<$ \\
2 & Medium Tree (M) & Ac, Ba, Bb, Bc, Ca, Da & B & $5-10$ & b & $3-7$ \\
3 & Big Tree (L) & Ad, Bd, Cb, Cc, Db & C & $10-15$ & c & $7-10$ \\
4 & Very Large Tree (LL) & Cd, Dc, Dd & D & $>15$ & d & $>10$ \\
\hline
\end{tabular}

Source: Irwan, 2007

\section{RESULTS AND DISCUSSION}

Mataram Merah Park had an area of $3490 \mathrm{~m} 2$, various facilities were available with various facilities, namely a children's playground, jogging track, discussion room, seating, financial literacy learning facilities, lighting, financial information boards, trash cans, seats for visitors. The existence of a city park with optimal quality was very important for a city, besides functioning as an ecological function, it also functioned as a public space, namely for interaction with urban communities (Miladan et al., 2019). Mataram Merah Park was a favorite for residents around the city to do activities, apart from being supported by adequate facilities, there was also various landscape vegetation to add aesthetic value. The majority of urban residents of various countries really felt the importance of the availability of urban park landscape vegetation for public health as well as for recreation (Strumse et al., 2006).

The vegetation in Mataram Merah Park after being identified were 29 types of plants consisting of 5 types of trees (17.24\%), 21 types of shrubs (72.41\%), 2 types of ground cover plants $(6,91 \%)$, and grass plants as much as 1 species (3.44\%). The selection of vegetation types was important because the determination was very much determined by the function of plants to reduce pollution, and was beneficial for water conservation, directional function and aspects of beauty. The function of plants in the landscape is to control views, climate, erosion, physical barriers, animal habitat and aesthetics (Suparwoko, 2012). In detail, the types and functions of vegetation in Mataram Merah Park, Kebayoran Baru, DKI Jakarta are presented in Table 2 below. 
Table 2. Data on the Types and Functions of Landscape Vegetation in Mataram Merah Park, Jakarta

\begin{tabular}{|c|c|c|c|c|c|c|c|c|c|c|}
\hline \multirow[b]{2}{*}{ No. } & \multirow[b]{2}{*}{ Local name } & \multirow[b]{2}{*}{ Latin name } & \multirow[b]{2}{*}{$\sum$} & \multicolumn{6}{|c|}{ Functions of Plants in Landscape } & \multirow[b]{2}{*}{$\begin{array}{c}\text { Tree Size } \\
*)\end{array}$} \\
\hline & & & & $\begin{array}{c}\text { Want to } \\
\text { have a } \\
\text { view }\end{array}$ & $\begin{array}{l}\text { Phys } \\
\text { ical } \\
\text { boun } \\
\text { dary }\end{array}$ & $\begin{array}{l}\text { Climate } \\
\text { Control }\end{array}$ & $\begin{array}{l}\text { Erosion } \\
\text { Control }\end{array}$ & $\begin{array}{c}\text { Anima } \\
1 \\
\text { Habita } \\
\mathrm{t}\end{array}$ & $\begin{array}{c}\text { Aestheti } \\
\text { cs }\end{array}$ & \\
\hline \multicolumn{11}{|c|}{ Tree } \\
\hline 1 & $\begin{array}{l}\text { Princess } \\
\text { earrings }\end{array}$ & Wrightia religiosa & 31 & & & & & $\mathbf{V}$ & $\mathbf{V}$ & $\mathbf{M}$ \\
\hline 2 & $\begin{array}{l}\text { Cambodia } \\
\text { Japan }\end{array}$ & Adenium spp & 1 & & & & $\mathbf{V}$ & & $\mathbf{V}$ & $\mathbf{M}$ \\
\hline 3 & Yellow palm & Dypsis lutescens & 6 & & $\mathbf{V}$ & $\mathbf{V}$ & $\mathbf{V}$ & & $\mathbf{V}$ & $\mathbf{S}$ \\
\hline 4 & Red palm & $\begin{array}{l}\text { Cyrtostachys lakka } \\
\text { Becc }\end{array}$ & 6 & & $\mathbf{V}$ & $\mathbf{V}$ & $\mathbf{V}$ & & $\mathbf{V}$ & $\mathbf{S}$ \\
\hline 5 & Sadeng palm & $\begin{array}{l}\text { Livistona } \\
\text { rotundifolia. }\end{array}$ & 2 & & $\mathbf{V}$ & & $\mathbf{V}$ & & $\mathbf{V}$ & $\mathbf{M}$ \\
\hline \multicolumn{11}{|c|}{ Shrubs } \\
\hline 6 & Sri Ivory & Saraca indica & 300 & & & $\mathbf{V}$ & $\mathbf{V}$ & $\mathbf{V}$ & $\mathbf{V}$ & \\
\hline 7 & Mill flower & & 579 & & & & & & & \\
\hline 8 & Blood symbol & $\begin{array}{l}\text { Excoecaria } \\
\text { cochinchinensis }\end{array}$ & 250 & & & & & & $\mathbf{V}$ & \\
\hline 9 & Paradise & Strelitzia reginae & 350 & & V & & & & $\mathbf{V}$ & \\
\hline 10 & Red Soka & Saraca Indica & 805 & & $\mathbf{V}$ & & $\mathbf{V}$ & & $\mathbf{V}$ & \\
\hline 11 & Mirten & Malpighia coccigera & 80 & $\mathbf{V}$ & $\mathbf{V}$ & & & & $\mathbf{V}$ & \\
\hline 12 & $\begin{array}{l}\text { Yellow } \\
\text { pandanus }\end{array}$ & Pandanus pygmaeus & 307 & & $\mathbf{V}$ & & $\mathbf{V}$ & & $\mathbf{V}$ & \\
\hline 13 & $\begin{array}{l}\text { Bromelia } \\
\text { flower }\end{array}$ & Bromeliasp. & 19 & & $\mathbf{V}$ & & $\mathbf{V}$ & & $\mathbf{V}$ & \\
\hline 14 & Aralea & Osmoxylon lineare & 891 & & $\mathbf{V}$ & & $\mathbf{V}$ & & $\mathbf{V}$ & \\
\hline 15 & White earrings & Acalypha australis & 220 & & & & & & $\mathbf{V}$ & \\
\hline 16 & Red earrings & Acalypha indica & 500 & & & & & & $\mathbf{V}$ & \\
\hline 17 & Centipede fern & Nephrolepissp. & 306 & & & & & & $\mathbf{V}$ & \\
\hline 18 & Heliconia zebra & Heliconia sp & 180 & $\mathbf{V}$ & $\mathbf{V}$ & & & & $\mathbf{V}$ & \\
\hline 19 & $\begin{array}{l}\text { Green paris } \\
\text { lilies }\end{array}$ & $\begin{array}{l}\text { Chlorophytum } \\
\text { comosum }\end{array}$ & 545 & & $\mathbf{V}$ & & $\mathbf{V}$ & & $\mathbf{V}$ & \\
\hline 20 & Marantha batik & Maranta leuconeura & 52 & & $\mathbf{V}$ & & $\mathbf{V}$ & & $\mathbf{V}$ & \\
\hline 21 & Lee kwan you & Vernonia elliptica & 30 & $\mathbf{V}$ & & & & & $\mathbf{V}$ & \\
\hline 22 & Tuber lilies & Liliumsp. & 225 & & & & & & $\mathbf{V}$ & \\
\hline 23 & Red shoots & Syzygium oleana & 420 & $\mathbf{V}$ & $\mathbf{V}$ & $\mathbf{V}$ & & & $\mathbf{V}$ & \\
\hline 24 & Rollia upright & Ruellia tuberosa $L$. & 340 & & $\mathbf{V}$ & & & $\mathbf{V}$ & $\mathbf{V}$ & \\
\hline 25 & $\begin{array}{l}\text { Rollia } \\
\text { collapsed }\end{array}$ & Ruellia tuberosa $L$. & 500 & & $\mathbf{V}$ & & & $\mathbf{V}$ & $\mathbf{V}$ & \\
\hline 26 & Taiwan beauty & Cuphea hyssopifolia & 100 & & $\mathbf{V}$ & & $\mathbf{V}$ & $\mathbf{V}$ & $\mathbf{V}$ & \\
\hline \multicolumn{11}{|c|}{ Ground Cover } \\
\hline 27 & $\begin{array}{l}\text { Brazil paris } \\
\text { lilies }\end{array}$ & Brazil paris lilies & 906 & & $\mathbf{V}$ & & $\mathbf{V}$ & & $\mathbf{V}$ & \\
\hline 28 & Red Erpah & Aerva sanguinolenta & & & $\mathbf{V}$ & & $\mathbf{V}$ & & $\mathbf{V}$ & \\
\hline \multicolumn{11}{|c|}{ Grass } \\
\hline 29 & $\begin{array}{l}\text { Mini elephant } \\
\text { grass }\end{array}$ & $\begin{array}{l}\text { Axonopus } \\
\text { compressus }\end{array}$ & $\begin{array}{c}261 \\
9 \\
\mathrm{~m} 2 \\
\end{array}$ & & & & $\mathbf{V}$ & & $\mathbf{V}$ & \\
\hline
\end{tabular}

Source: Field Observation Data (2020)

Based on Table 2, it shows that with a total of 906 plants. Mataram Merah among the 29 types of plants in Mataram Park was generally planted with vegetation Merah Park, the dominant type of which functions aesthetically rather than landscape vegetation is the type of functionally. ground cover, namely lily paris brazil 
aesthetic functions, but how animals can be present in the environment needed to be added with the large trees and small trees, especially those with flower because birds and insects need suitable vegetation as their habitat (Irwan et al, 2012).

The results of the vegetation analysis in Mataram Park showed that there were 28 types of landscape plants that functioned as aesthetics (96.55\%) and 4 types of plants that functioned as view control (13.80\%). There were 18 types of plants whose landscape vegetation function as a physical barrier $(62.07 \%)$. The functions of vegetation as erosion control are 15 species (51.72\%); as climate controllers as many as 4 types (13.79\%); the function of vegetation for animals are 5 species (17.24\%). Each vegetation had different functions and benefits. The composition of vegetation should be adjusted to the function of the area, so that its function in city parks can be realized optimally (Soemaerno et al., 2013). The composition of the right vegetation in urban green open spaces such as city parks was the first step to create city parks that had an ecological function as the main support and aesthetic function as a support.

\section{CONCLUSION}

From this study it can be concluded that in Mataram Merah Park, the dominant vegetation structure composition is shrubs, followed by trees (small / S and medium / M), ground cover and grass. The composition of this vegetation had an impact on function vegetation at the study site. The highest was the aesthetic function, followed by physical barrier functions, erosion control, functions for animals, visual control and climate control. Thus, the need for certain functions of a city park needs to pay attention to the composition of the vegetation structure.

\section{ACKNOWLEDGMENT}

In this research, the authors received help from various parties. Thank you to Dinas Pertamanan Jakarta, for the data provided; Universitas Trisakti; Department of Landscape Architecture for provides research funding and the research team in carrying out research and writing this manuscript.

\section{REFERENCES}

Alfian H \& Kurniawan H. (2010). Konsep Pemilihan Vegetasi Lansekap pada Taman Lingkungan di Bunderan Waru Surabaya. Jurnal Buana Sains., 10 (2): 181-185.

Ayu PA. (2019). Peran Ruang Terbuka Hijau Dalam Citra Kota Studi Kasus: Taman Suropati, Jakarta. Jurnal Ilmiah Desain dan kontruksi, 18 (1): 53-64.

Brimblecombe P, \& Xing Y. (2019). Role of vegetation in deposition and dispersion of air pollution in urban parks. Journal Atmospheric Environment, (201):73-81. https://doi.org/10.1016/j.atmosenv.2018.12.027. 
Carpenter, P. L., T. D. Walker \& F. O. Lanphear. (1975). Plants in The Landscape. W. H. Freeman Co., San Fransisco.

Hanan, H. (2013). Open Space as Meaningful Place for Students in ITB Campus. Procedia- Social and Behavioral Sciences. 85:308-317.

Herdiansyah H \& Prakoso P. (2019). Analisis Implementasi 30\% Ruang Terbuka Hijau Di DKI Jakarta. Majalah Ilmiah Globe, 21(1): 17-25.

Irwan S.N.R. Khaisol A \& Hasanbahri S. (2012). Fungsi Vegetasi Pada Ruang Hijau Dan Hutan Kota Untuk Pengembangan Lanskap Ecopesantren. Prosiding Seminar Nasional Arsitektur Islam 2 "Konstribusi Arsitektur Islam dalam Mengatasi Masalah Perkotaan" Surakarta, (24 Mei) 2012. 131-136.

Irwan, S.N.R. (2007). Study on human thermal comfort and human activity in the treeshaded areas in the green space of the tropical country. Case Study: The Prambanan Park, Yogyakarta, Indonesia. Bulletin of Chiba University. Japan.

Miladan N, Soedwiwahjonol, \& Pratomol A. (2019). Kualitas Taman Kota Sebagai Ruang Publik Di Kota Surakarta
Berdasarkan Persepsi Dan Preferensi Pengguna, Jurnal Desa-Kota. 1(1): 84-94.

Nurbalkis, N. (2016). Arahan Perancangan Taman Kota Sebagai Pemenuhan Kebutuhan Ruang Publik di Kecamatan Kota Juang. Jurnal Ruang, 2(3): 207-210.

Rizkiyah, Z, Nugrahalia, M., \& Lubis, R., (2016), Penetapan Bobot Timbulan Sampah Rumah Tangga Di Tiga Lingkungan Di Kelurahan Bantan Kecamatan Medan Tembung Kota Medan, BioLink, Vol. 3 (1), Hal: 65-74

Soemaerno, Yanuawiadi B, \& Lestari I. (2013). Analisis Kesesuaian Vegetasi Lokal Untuk Ruang Terbuka Hijau Jalur Jalan di Pusat Kota Kupang. Jurnal Pembangunan Alam Lestari, 4(1): 140-148. Suparwoko. (2012). Analisis Pemilihan Jenis Tanaman dan Keamanan Pohon pada Lansekap Jalan Ruang Terbuka Hijau Tempat Pembuangan Akhir Sampah Piyungan Yogyakarta. Jurnal Sains dan Teknologi Lingkungan, 4(2): 125-130.

Strumse E, Thraneb C, Ostdahla T, \& Bjerkea T. (2006). Vegetation density of urban parks and perceived appropriateness for recreation. Urban Forestry \& Urban Greening. 5, 35-44. doi:10.1016/ j. ufug. 2006.01.006.

Yuantika \& Sulistiyowati TI. (2019). Jenis-jenis Pohon Peneduh di Taman Kota Kediri. Jurnal Biologi dan Pembelajarannya, 6(1): 13 -15. 